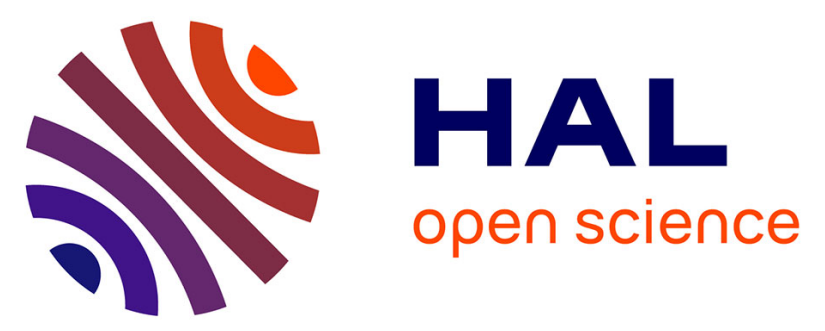

\title{
Long-term follow-up after autologous adipose-derived stromal vascular fraction injection into fingers in systemic sclerosis patients
}

A. Daumas, Jérémy Magalon, E. Jouve, R. Truillet, D. Casanova, L. Giraudo, J. Veran, Audrey Benyamine, Francoise Dignat-George, G. Magalon, et al.

\section{To cite this version:}

A. Daumas, Jérémy Magalon, E. Jouve, R. Truillet, D. Casanova, et al.. Long-term follow-up after autologous adipose-derived stromal vascular fraction injection into fingers in systemic sclerosis patients. Current Research in Translational Medicine, 2017, 65 (1), pp.40-43. 10.1016/j.retram.2016.10.006 . hal-01792172

\section{HAL Id: hal-01792172 \\ https://hal-amu.archives-ouvertes.fr/hal-01792172}

Submitted on 18 May 2018

HAL is a multi-disciplinary open access archive for the deposit and dissemination of scientific research documents, whether they are published or not. The documents may come from teaching and research institutions in France or abroad, or from public or private research centers.
L'archive ouverte pluridisciplinaire HAL, est destinée au dépôt et à la diffusion de documents scientifiques de niveau recherche, publiés ou non, émanant des établissements d'enseignement et de recherche français ou étrangers, des laboratoires publics ou privés. 


\title{
Current Research in Translational Medicine - Brief communication
}

Long-term follow-up after autologous adipose-derived stromal vascular fraction injection into fingers in systemic sclerosis patients

Short title: autologous adipose-derived stromal vascular fraction in scleroderma

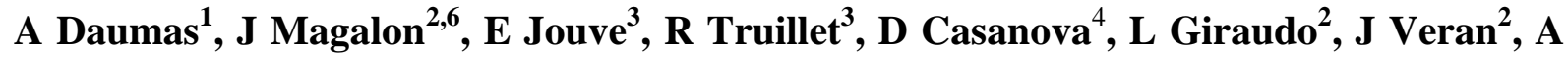
Benyamine $^{1}$, F Dignat-George ${ }^{5,6}$, G Magalon $^{3,4}$, F Sabatier ${ }^{2,6}$, B Granel ${ }^{1,6}$
\end{abstract}

${ }^{1}$ Assistance Publique Hôpitaux de Marseille (APHM), CHU of Marseille, Internal Medicine Department, Marseille, France

${ }^{2}$ Culture and Cell Therapy Laboratory, INSERM CBT-1409, Assistance Publique Hôpitaux de Marseille (AP-HM), Aix Marseille University, France

${ }^{3}$ APHM, Centre d'Investigation Clinique - Centre de Pharmacologie Clinique et d'Evaluations Thérapeutiques (CIC-CPCET), CHU of Marseille, Marseille, France

${ }^{4}$ APHM, CHU of Marseille, Plastic Surgery Department, Marseille, France

${ }^{5}$ APHM, CHU of Marseille, Hematology and Vascular Biology Laboratory, Marseille, France

${ }^{6}$ Aix Marseille Univ, INSERM, VRCM, UMR_S 1076, Marseille, France

Corresponding author

Brigitte GRANEL, MD

Assistance Publique Hôpitaux de Marseille (APHM), Hôpital Nord,

Internal Medicine Department

13915 Marseille, FRANCE

Phone: 334919687 11 Fax: 33491968080

E mail: bgranel@ap-hm.fr 


\section{ABSTRACT}

\section{Introduction}

Hand involvement confers a substantial handicap in work and daily activities in patients with Systemic sclerosis (SSc). Autologous adipose-derived stromal vascular fraction is as an easily accessible source of cells with regenerative effects. We previously performed a phase I openlabel clinical trial (NTC01813279) assessing the safety of subcutaneous injection of autologous adipose-derived stromal vascular fraction. Six and 12 month data have been reported. As patients were followed in our medical centre, we report their longer term outcome beyond the end of the trial.

\section{Patients and method}

Twelve females, mean age $54.5 \pm 10.3$ years, initially enrolled in the clinical trial were assessed during a scheduled medical care, which took place between 22 and 30 months after treatment. Results

Multiple patient-reported outcomes showed sustained improvement, in comparison with the assessment performed just before surgery: $62.5 \%$ in the Cochin Hand Function Scale, $51.1 \%$ in the Scleroderma Health Assessment Questionnaire, 33.1\% in hand pain, and $88.3 \%$ in the Raynaud Condition Score. A decrease in the number of digital ulcers number was noted. Mobility, strength and fibrosis of the hand also showed improvement. None of the 8 patients who had previously received iloprost infusion required new infusion.

\section{Conclusion}

Despite the limits of an open label study, the data are in favour of the long-term safety of the adipose-derived stromal vascular fraction injection. Two randomized double blind, placebocontrolled trials of this therapeutic agent are ongoing in the USA (NCT02396238) and in France (NCT02558543) and will help determine the place of this innovative therapy for SSc patients. 
KEYWORDS: systemic sclerosis, stromal vascular fraction, adipose tissue 


\section{Introduction}

Hand involvement is frequent in Systemic sclerosis (SSc) and confers a substantial handicap in work and daily activities [1]. To date, clinical care for the hand relies on vasodilators, cold and trauma protection, and regular physiotherapy. No antifibrotic therapy has proven effective.

The regenerative properties of cells derived from adipose tissue have been explored for over a decade. In 2002, Zuk identified and described a putative population of multipotent stem and progenitor cells within the stromal vascular fraction (SVF) cell population derived by enzymatic digestion of adipose tissue [2]. The SVF is composed of blood cells, fibroblasts, endothelial cells and their progenitors, pericytes, adipose stromal/stem cells (ASC) and preadipocytes. This population has been reported to possess multiple angiogenic, antiinflammatory, immunomodulatory and regenerative properties [3].

We previously performed a phase I open-label single center clinical trial, called SCLERADEC (NTC01813279) assessing the safety and efficacy of adipose-derived stromal vascular fraction (ADSVF) in $12 \mathrm{SSc}$ patients followed for 6 months [4], and later reported their extending outcome at 12 months [5]. We took advantage of routine medical follow-up of these patients to assess their longer term outcome.

\section{Patients and methods}

Patients: Twelve SSc patients, all female, were enrolled from December 2012 through May 2013. The population was composed of 8 subjects with limited cutaneous SSc and 3 with diffuse disease. Three patients were classified as early SSc disease $(<4$ years). Subjects had mean age of $54.5 \pm 10.3$ years and body mass index of $22.0 \pm 2.1 \mathrm{~kg} / \mathrm{m}^{2}$. As part of the inclusion criteria all subjects had hand disability of at least 20 points using the Cochin Hand Function Scale (CHFS). 
Procedures: Adipose tissue collection, ADSVF extraction and quality controls have previously been described [4-6]. ADSVF was obtained within 2 hours after lipoaspiration using the automated processing Celution800/CRS system (Cytori Therapeutics, San Diego, USA). An average of $3.76 \pm 1.85 \times 10^{6}$ cells was injected into each finger as previously described [3-5, with video of the surgical technique in 6].

Outcome: After completion of the trial patients continued their routine medical appointments in the internal medicine department. This allowed us to assess their hand function and other parameters using the same evaluators and same tools as those applied within the trial [4]. This was performed during a single visit occurring within the range of 22 to 30 months from the date of the ADSVF injection.

Data analysis: Continuous data were summarized by mean \pm standard deviation and median [minimum-maximum]. CHFS, Scleroderma Health Assessment Questionnaire (SHAQ), Raynaud's Condition Score (RCS) and hand pain visual analogue scale (VAS) were analyzed as co-primary outcomes. Mean changes from baseline were analyzed using mixed model with cutaneous form (diffuse or limited) as fixed effect and time (2, 6, 12 and 24 months) as repeated effect. Least square mean differences form baseline were tested with Tukey adjustment. Significance was set at $\mathrm{p}<0.05$ level after adjustment.

\section{Results}

Consistent with prior reports [4,5], no evidence of treatment-related adverse events was noted in any patient. Results of functional assessments are shown in Table 1 and Figure 1. Results show that the benefit reported at the 6 month time point of the trial is sustained at 22-30 months. For example, the long-term follow-up data for CHFS, SHAQ, and RCS endpoints showed $62.5 \%, 51.1 \%$ and $88.3 \%$ improvement over baseline respectively. It is worth noting that the decrease of the VAS for hand pain which had lost statistical significance at 12 months post-surgery [5] regained significance at 24 months (33.1\% decrease from baseline) (Figure 
1). Improvement in objective endpoints such as Jamar grip strength reported at 6 months was sustained in the current assessment while pinch strength showed continued improvement. The modified Rodnan Skin Score focused on hands decreased from 10.9 \pm 4.9 at baseline to $8.8 \pm 5.9$ although this difference did not achieve statistical significance. Lateral range of motion of the fingers assessed with the first corner distance and the sum of the 2-4th corner distances did not change significantly. The sum of pad to distal palmar line distances decreased over time for both hands without reaching significance p-value. The Kapandji score was high at baseline and did not change over time. The total number of digital ulcers (DU) number was 15 at entry and 6 at last visit.

Mean global disease severity score (Medsger scale) remained stable: 2.5 [1-3] at baseline and 2.5 [0-3] at last clinical assessment. Comparison of changes in medical drugs from baseline to last visit showed that none of the 8 patients who had previously received iloprost infusion required new infusion. One patient with diffuse cutaneous SSc was prescribed an immunosuppressive medication due to progression of skin fibrosis and another patient with diffuse cutaneous SSc received sildenafil for recurrent ischemic digital ulcer. Three patients previously treated with a calcium channel blocker stopped this treatment due to side effect without worsening of Raynaud's phenomenon.

\section{Discussion}

While the current report is limited by the repetition of hand assessment in an extended followup from an original phase I open label study and the potential bias related to natural course of the disease and the seasonal effect, the long-term assessment is in favour of safety and durability of the effect. Given the costs associated with preparation of an autologous autologous cell therapy product to standards required by local, national, and European regulatory authorities it is important to assess the apparent durability of the response in order to begin to build a pharmaco-economic argument for or against this therapy. The current study, with evidence of apparently sustained—possibly progressive-improvement and the reduction in need for costly medications such as iloprost, represents the first step in building the data set needed for a cost-benefit assessment. Due to the lack of a placebo group, we are aware that we cannot be definitive about the causal link between the long-term hand 
improvement and ADSVF injection. However, it appears somewhat unlikely that the substantial magnitude of change over such a prolonged period could be attributed to a placebo effect and is unlikely to represent spontaneous sustained positive changes in the natural history of the disease. Rather, from a physiopathological point of view, we believe that the combined and synergistic pro-angiogenic, anti-inflammatory, anti-fibrotic and immunomodulatory effects possessed by the ASC and other progenitor cells inside the ADSVF [3] could explain these clinical results. Of course, the final determination of this question will depend upon the results of the robust randomized, placebo-controlled trials such as the two trials currently underway in France and in the USA.

\section{Conclusion}

Although interpretation of these results is hampered by the lack of a control group, the use of autologous ADSVF is an innovative therapy which appears to provide benefit for patients suffering from SSc who have hand dysfunction. Two randomized double blind, placebocontrolled clinical trials with this form of ADSVF are ongoing: Scleroderma Treatment with Celution Processed Adipose Derived Regenerative Cells (STAR) in USA and SCLERADEC 2 in France. Such evidence will help guide health care professionals on the place of this therapy for SSc patients. 
All authors participated in the writing of the manuscript and the interpretation of the data. They all approved the manuscript.

Acknowledgements: We thank the French Scleroderma Research Group (GFRS), the Centre d'Investigation Clinique (CIC) for having welcomed the patients, Joelle Micallef and Estelle Charles-Baumel from the Centre d'Investigation Clinique - Centre de Pharmacologie Clinique et d'Evaluations Thérapeutiques (CIC-CPCET).

Funding: We acknowledge support from Cytori for having given free devices and consumables for ADSVF surgical procedure.

Disclosure statement: Prof Magalon has received honoraria for consulting services for Cytori Therapeutics. The others authors declared no conflicts of interest. 


\section{References:}

[1] Guillevin L, Hunsche E, Denton CP, Krieg T, Schwierin B, Rosenberg D, et al; DUO Registry Group. Functional impairment of systemic scleroderma patients with digital ulcerations: results from the DUO Registry. Clin Exp Rheumatol 2013;31:71-80.

[2] Zuk PA, Zhu M, Ashjian P, De Ugarte DA, Huang JI, Mizuno H, et al. Human adipose tissue is a source of multipotent stem cells. MolBiol Cell 2002;13:4279-95.

[3] Guillaume-Jugnot P, Daumas A, Magalon J, Sautereau N, Veran J, Magalon G, et al. State of the art. Autologous fat graft and adipose tissue-derived stromal vascular fraction injection for hand therapy in systemic sclerosis patients. Curr Res Transl Med 2016;64:35-42. [4] Granel B, Daumas A, Jouve E, Harlé JR, Nguyen PS, Chabannon C, et al. Safety, tolerability and potential efficacy of injection of autologous adipose-derived stromal vascular fraction in the fingers of patients with systemic sclerosis: an open-label phase I trial. Ann Rheum Dis. 2015;74:2175-82.

[5] Guillaume-Jugnot P, Daumas A, Magalon J, Jouve E, Nguyen PS, Truillet R, et al. Autologous adipose-derived stromal vascular fraction in patients with systemic sclerosis: 12month follow-up. Rheumatology [Oxford]. 2016;55:301-6. 
Table 1: Outcome of assessed parameters from baseline to last complete evaluation 


\begin{tabular}{|c|c|c|c|c|c|c|}
\hline & \multicolumn{3}{|c|}{$\begin{array}{c}\text { Mean } \pm \text { SD } \\
\text { Median [min-max] }\end{array}$} & \multirow{2}{*}{$\begin{array}{c}\text { Least square mean } \\
\text { difference } \\
\text { [adjusted } 95 \% \mathrm{CI} \text { ] }\end{array}$} & \multicolumn{2}{|c|}{$\begin{array}{c}\text { Test of LSM difference at } \\
\text { M24 }\end{array}$} \\
\hline & Baseline & 6 months & 22-30 months & & $\begin{array}{l}\text { raw p- } \\
\text { value }\end{array}$ & $\begin{array}{c}\text { p-value Tukey } \\
\text { adjustment }\end{array}$ \\
\hline SHAQ Score /3 & $\begin{array}{c}1.4 \pm 0.3 \\
1.4[0.8-2.1]\end{array}$ & $\begin{array}{c}0.8 \pm 0.4 \\
0.8[0.0-1.5]\end{array}$ & $\begin{array}{c}0.7 \pm 0.5 \\
0.7[0.0-1.9]\end{array}$ & $\begin{array}{c}-0.6 \\
{[-1.1 ;-0.1]}\end{array}$ & 0.0006 & 0.0051 \\
\hline CHFS total /90 & $\begin{array}{c}48.5 \pm 10.8 \\
48.5[30.0-69.0]\end{array}$ & $\begin{array}{c}21.2 \pm 15.4 \\
20.0[0.0-48.0]\end{array}$ & $\begin{array}{c}18.6 \pm 13.8 \\
13.0[0.0-45.0]\end{array}$ & $\begin{array}{c}-28.6 \\
{[-43.0 ;-14.2]}\end{array}$ & $<.0001$ & $<.0001$ \\
\hline RCS /10 & $\begin{array}{c}7.2 \pm 0.9 \\
7.5[6.5-8.0]\end{array}$ & $\begin{array}{c}2.9 \pm 1.4 \\
3.0[2.5-3.0]\end{array}$ & $\begin{array}{c}0.8 \pm 0.9 \\
0.5[0.0-2.5]\end{array}$ & $\begin{array}{c}-6.3 \\
{[-7.7 ;-5.0]}\end{array}$ & $<.0001$ & $<.0001$ \\
\hline Hand pain VAS /100 & $\begin{array}{c}59.4 \pm 17.2 \\
58.5[50.0-72.5]\end{array}$ & $\begin{array}{c}17.8 \pm 15.3 \\
13.6[9.0-26.0]\end{array}$ & $\begin{array}{c}29.5 \pm 25.2 \\
32.5[0.0-72.0]\end{array}$ & $\begin{array}{c}-26.6 \\
{[-50.1 ;-3.0]}\end{array}$ & 0.0025 & 0.02 \\
\hline $\begin{array}{l}\text { Jamar score (kg) } \\
\text { Dominant hand }\end{array}$ & $\begin{array}{c}16.0 \pm 5.8 \\
15.0[9.0-26.5]\end{array}$ & $\begin{array}{c}19.4 \pm 7.4 \\
20.0[5.0-30.0]\end{array}$ & $\begin{array}{c}19.0 \pm 6.1 \\
19.0[8.0-29.0]\end{array}$ & $\begin{array}{c}3.2 \\
{[-3.5 ; 10.0]}\end{array}$ & 0.1793 & 0.6512 \\
\hline $\begin{array}{l}\text { Jamar score (kg) } \\
\text { Non-dominant hand }\end{array}$ & $\begin{array}{c}14.9 \pm 6.1 \\
14.0[8.0-30.0]\end{array}$ & $\begin{array}{c}17.6 \pm 8.0 \\
20.0[3.5-29.0]\end{array}$ & $\begin{array}{c}18.6 \pm 6.3 \\
18.0[6.0-30.0]\end{array}$ & $\begin{array}{c}4.3 \\
{[-1.6 ; 10.2]}\end{array}$ & 0.0421 & 0.2398 \\
\hline $\begin{array}{l}\text { Pinch score }(\mathbf{k g}) \\
\text { Dominant hand }\end{array}$ & $\begin{array}{c}1.3 \pm 1.1 \\
0.9[0.2-4.1]\end{array}$ & $\begin{array}{c}2.3 \pm 1.3 \\
2.0[0.9-5.4]\end{array}$ & $\begin{array}{c}5.7 \pm 1.8 \\
5.0[3.5-9.0]\end{array}$ & $\begin{array}{c}4.2 \\
{[2.7 ; 5.8]}\end{array}$ & $<.0001$ & $<.0001$ \\
\hline $\begin{array}{c}\text { Pinch score (kg) } \\
\text { Non-dominant hand }\end{array}$ & $\begin{array}{c}1.3 \pm 0.9 \\
0.9[0.2-3.2]\end{array}$ & $\begin{array}{c}2.1 \pm 1.0 \\
2.0[0.7-3.6]\end{array}$ & $\begin{array}{c}5.5 \pm 1.5 \\
5.0[4.5-6.0]\end{array}$ & $\begin{array}{c}3.9 \\
{[2.6 ; 5.2]}\end{array}$ & $<.0001$ & $<.0001$ \\
\hline mRSS applied to hand /18 & $\begin{array}{c}10.9 \pm 4.9 \\
11.5[3.0-18.0]\end{array}$ & $\begin{array}{c}9.9 \pm 6.0 \\
12.0[1.0-18.0]\end{array}$ & $\begin{array}{c}8.8 \pm 5.9 \\
9.5[0.0-16.0]\end{array}$ & $\begin{array}{c}-1.5 \\
{[-4.7 ; 1.7]}\end{array}$ & 0.1828 & 0.6587 \\
\hline $\begin{array}{l}\text { 1st corner distance }(\mathbf{m m}) \\
\text { Dominant hand }\end{array}$ & $\begin{array}{c}105.6 \pm 24.7 \\
112.0[57-142]\end{array}$ & $\begin{array}{c}112.9 \pm 29.2 \\
118.5[57-154]\end{array}$ & $\begin{array}{c}121.4 \pm 27.9 \\
126.0[56-155]\end{array}$ & $\begin{array}{c}15.2 \\
{[-4.7 ; 35.2]}\end{array}$ & 0.0353 & 0.2084 \\
\hline $\begin{array}{l}\text { 1st corner distance }(\mathbf{m m}) \\
\text { Non-dominant hand }\end{array}$ & $\begin{array}{c}115.8 \pm 24.5 \\
118.5[65-152]\end{array}$ & $\begin{array}{c}122.3 \pm 20.9 \\
121.5[88-155]\end{array}$ & $\begin{array}{c}128.7 \pm 23.4 \\
130.5[90-174]\end{array}$ & $\begin{array}{c}13.4 \\
{[-6.0 ; 32.7]}\end{array}$ & 0.0554 & 0.2974 \\
\hline $\begin{array}{l}\text { Sum of corners distances [mm] } \\
\text { Dominant hand }\end{array}$ & $\begin{array}{c}133.9 \pm 18.5 \\
130.5[110-168]\end{array}$ & $\begin{array}{c}131.2 \pm 20.7 \\
131.0[94-169]\end{array}$ & $\begin{array}{c}130.4 \pm 30.4 \\
134.0[80-1179]\end{array}$ & $\begin{array}{l}2.7 \\
{[-17.8 ; 23.3]}\end{array}$ & 0.7057 & 0.9953 \\
\hline $\begin{array}{c}\text { Sum of corners distances [mm] } \\
\text { Non-dominant hand }\end{array}$ & $\begin{array}{c}132.1 \pm 24.6 \\
139.0[73-158]\end{array}$ & $\begin{array}{c}133.7 \pm 29.4 \\
139.5[64-166]\end{array}$ & $\begin{array}{c}135.0 \pm 24.2 \\
138.0[100-186]\end{array}$ & $\begin{array}{c}5.7 \\
{[-10.2 ; 21.5]}\end{array}$ & 0.3136 & 0.8442 \\
\hline $\begin{array}{c}\text { Sum of Pad/DPL distance } \\
\text { [mm] Dominant hand }\end{array}$ & $\begin{array}{c}52.0 \pm 46.5 \\
49.5[0-160]\end{array}$ & $\begin{array}{c}47.3 \pm 43.8 \\
46.0[0-115]\end{array}$ & $\begin{array}{c}25.9 \pm 45.0 \\
0.0[0-110]\end{array}$ & $\begin{array}{c}-29.8 \\
{[-62.3 ; 2.7]}\end{array}$ & 0.0124 & 0.0858 \\
\hline
\end{tabular}




\begin{tabular}{|c|c|c|c|c|c|c|}
\hline $\begin{array}{c}\text { Sum of Pad/DPL distance [ } \mathbf{m m} \\
\text { ]Non-dominant hand }\end{array}$ & $\begin{array}{c}48.1 \pm 54.5 \\
32.0[0-144]\end{array}$ & $\begin{array}{c}46.8 \pm 52.0 \\
38.5[0-160]\end{array}$ & $\begin{array}{c}30.2 \pm 57.0 \\
0.0[0-165]\end{array}$ & $\begin{array}{c}-22.7 \\
{[-57.7 ; 12.4]}\end{array}$ & 0.0719 & 0.3612 \\
\hline $\begin{array}{c}\text { Kapandji score/10 } \\
\text { Dominant hand }\end{array}$ & $\begin{array}{c}8.0( \pm 1.4) \\
8.0[7.0-9.0]\end{array}$ & $\begin{array}{c}8.4 \pm 1.7 \\
9.3[5.0-10.0]\end{array}$ & $\begin{array}{c}8.5( \pm 1.6) \\
9.0[7.5-10.0]\end{array}$ & $\begin{array}{c}0.6 \\
{[-0.6 ; 1.7]}\end{array}$ & 0.1574 & 0.6050 \\
\hline $\begin{array}{l}\text { Kapandji score/10 } \\
\text { Non-dominant hand }\end{array}$ & $\begin{array}{c}8.5( \pm 1.2) \\
9.0[8.0-9.5]\end{array}$ & $\begin{array}{c}8.8 \pm 1.3 \\
9.0[6.0-10.0]\end{array}$ & $\begin{array}{c}8.8( \pm 1.3) \\
9.0[8.0-10.0]\end{array}$ & $\begin{array}{c}0.4 \\
{[-0.7 ; 1.5]}\end{array}$ & 0.3068 & 0.8371 \\
\hline
\end{tabular}

SD: Standard Deviation; SHAQ: Scleroderma Health Assessment Questionnaire, score ranged from 0=no disability, to 30=severe disability; CHFS:

Cochin Hand Function Scale, 0=performed without difficulty, to 5=impossible to do. Disability was recorded as the total score (range 0-90); VAS: Visual Analogue Scale for hand pain (0-100); RCS: Raynaud's Condition Score recording the frequency and severity of the attack on a scale from 0 to 10; Grip and pinch strength was assessed using a Jamar and pinch dynamometers; mRSS: Modified Rodnan Skin Score applied to the hands assessed skin thickening on the dorsal hand and the first and second phalanges of the most affected finger, scale $0=n o$ skin fibrosis, to $18=$ maximum fibrosis (3 tested sites for each hand); Lateral range of motion of the fingers was performed by measuring the distance between the thumb and index finger ( $1^{\text {st }}$ corner) and the sum of the distances between the four fingers $\left(2^{\text {nd }}, 3^{\text {rd }}\right.$, and $4^{\text {th }}$ corners $)$ upon maximum stretch; Finger pad to distal palmar line (DPL) assessed fingers' flexion (mm); Kapandji Score assessed opposition of the thumb, scale 0=impossible to 10=complete. 
Figure 1: Evolution of the 4 main parameters after 2 years of the procedure 